\title{
Evaluation of Transemarang Shelters on Diponegoro University Campus Area
}

\author{
Bangun IR Harsritanto ${ }^{1, *}$, Rona Fika Jamila ${ }^{2}$, Agasthia Villianggie ${ }^{1}$ \\ ${ }^{1}$ Department of Architecture, Diponegoro University, Semarang, Indonesia \\ ${ }^{2}$ Department of Architecture, Mercu Buana University, Jakarta, Indonesia
}

Received February 25, 2020 ; Revised June 24, 2020; Accepted July 7, 2020

Copyright $\bigcirc 2020$ by authors, all rights reserved. Authors agree that this article remains permanently open access under the terms of the Creative Commons Attribution License 4.0 International License

\begin{abstract}
The Trans buses are efforts to help people to reduce the usage of private personal vehicles and switch into public vehicles rides. Semarang is one of the metropolitan cities in Indonesia as the provincial capital of Central Java, which has had the Bus Rapid Transportation (BRT). The purpose of the research is to evaluate the Transemarang bus shelter on the Diponegoro University area related to the locations, conditions, and user perceptions. Literature and regulation studies were performed to arrange the evaluation sheet; site observation and questionnaire were functioned to evaluate the existing and collect data of user's perceptions. The conditions of Transemarang bus shelters on Diponegoro University area inadequate and not properly installed that bring dissatisfaction from the users. The previous researches were conducted on user satisfaction, policy, and tracking technology. This study was spotted from the architectural view which connecting the physical buildings, human as users, environments design, and universal design principles.
\end{abstract}

Keywords Transportation, Shelter, Evaluation, Universal Design, Transemarang

\section{Introduction}

The first country that operates Bus Rapid Transportation (BRT) is Brazil in 1974 at Curitiba city. At that time, this new concept had the purpose of delivering a large capacity of people with premium comfort level, high security, and punctual time priority. After Brazil adapted the BRT, this transportation system spread out to Central America and South America in the middle of the 1970s. However, Asia adopted it in the era 2000 in a limited area and concentrated on metropolitan districts. BRT could mention the well-integrated BRT system in Asia at Nagoya-Japan and the Taipei-China Democratic Republic at that period (Firmanda, 2013).

Vast cities and expansive metropolitan in Indonesia are vastly experiencing numerous growth of personal vehicles or private transportation recently. This condition proved to bring high impacts on crowded to chaotic traffic in the urban area, peripheral, and suburban. The Indonesia government, in this case, the Department of Transportation, which is a related bureau of transportation, push their limits to decrease the level of traffic density by installing public facilities, such: Bus Rapid Transportation (Trans Buses). The Trans buses is an effort or helping people to reduce the usage of private personal vehicles and switch into public vehicles rides (Irfana, Nugraha, \& Awaluddin, 2019). Regarding this chaotic situation, not all Indonesia metropolitan city has this Trans Bus. Just several cities like Jakarta, Semarang, Solo, Yogyakarta, Makassar, and Bandung already adopted and operated this BRT System this decade to reduce the significant number of traffic jams in their area (Putri, 2014). Furthermore, several BRT systems in that city are entering a new competition with the latest transportation system based on online applications (Silalahi, Handayani, \& Munajat, 2017).

Semarang is one of the metropolitan cities in Indonesia as the provincial capital of Central Java which has had the Bus Rapid Transportation (BRT) since 2009 and has still been growing until present with 6 (six) corridors in their coverage. The Semarang bus rapid transportation is shortly named as Transemarang. The transemarang is using a journey pass which allows the customer to pay one ticket for a trip and no additional fee on the transit shelter as long they didn't go out from the transit bus shelters to change their corridors. Transemarang applied the one-stop bus system, which only stops and drops the passengers off in their shelter only (Putri, 2014).

The shelter is a public infrastructure for passengers to drop off and pride on bus stop areas with protection from the not suitable climates and environments. That special 
function made the shelter different from the bus stop. In further words, the bus stop might not be a shelter, but a bus shelter is a bus stop. The accommodations were built to provide security and comfort for the passengers, bus crews, and local governments in their transportation-users interactions (Minister of Transportation, 1993). The distance between the shelters and the condition of it is also the priority in ensuring the quality of accommodations.

All buildings shall provide accessibility for all users regarding citizen equality justice in every aspect of living. In aims to do that's, universal design principles shall be applied on the instalment and developments. The character of building accessibilities is the connection to the building, from the building and inside the building (vertical and horizontal access) with evert infrastructures. The application of universal design principles must consider the requirement and ability of disability citizens, elderly and pregnant mothers (Minister of Public Works and People Settlements, 2017).

Customer satisfaction is the key to build and improve customer loyalty. Bunch of benefits can be obtained and gained by the industries from the high level of customer satisfaction. More benefits can be obtained, such as increasing loyalty, reducing the risk of a customer turning cycles, lowering the customer sensitivity toward ticket fares, decreasing marketing cost, and stepping down the operation cost on over customer situations (Aminah \& Zaenuri, 2019). A company with well-supported facilities can persuade the customers to experience the product repeatedly and make more relaxed and more comfortable access toward the services and transactions (Irawan, 2004).

Regarding the explanation above, this paper aims to descriptively evaluate the Transemarang bus shelter on the Diponegoro University area with a specific focus on the locations by the government regulation, the design conditions by the universal design guidelines, and user perceptions using satisfaction questionnaire. The novelties of physical and location evaluation research bring this paper originally, and the result would be a score to be suggested as key improvement points for better bus Transemarang shelter designs.

\section{Method}

The research location limitation is in Universitas Diponegoro, Tembalang on Jl. Prof. Sudharto, Semarang. In further detail of the locations are the route and shelters of BRT Trans Semarang on Jl. Prof. Sudharto. The studied BRT Semarang shelters were spread on 6 shelter points on Diponegoro University. Later on, the discussed cases were the shelter distance, the shelter condition of accessibilities (the connecting path, ramp, stairs, and doors) toward Diponegoro University shelters.

The site observation and questionnaire collection were operated during day time (morning 8AM-5PM) when people do their activities on seven consecutive days. The selections of date are 3rd 9th march 2019 of the final week on the spring semester to gain more respondents and various conditions of shelters.

The tools for this study were named as:

a. Literature (government regulations, related journals)

c. Observation plan and schedules

d. Pictures of studied objects

f. Distance measurements

g. Sketch books

h. smartphone with sound and video recording applications

The literature and regulation studies were performed to arrange the evaluation sheet, site observation and questionnaire were functioned to evaluate the existing and collect data of user's perceptions. Descriptive analyses were conducted for all study variables. A comparative study holds simple research by comparing at least two kinds of literature to bring a result. This study uses multidisciplinary in a new guideline (Harsritanto B. I., 2018).

\section{Evaluation Result and Discussion}

\section{Existing Shelters}

The bus trans Semarang's shelter in Universitas Diponegoro was built as the corridor VI instalments in Semarang. The underlying condition of the bus shelter is a box shape raised floor from the street, roof, access of ramp and stair with several different dimensions (figure 1) in several location spots of Universitas Diponegoro campus are (figure 2). The particular case of university shelters made the construction be supported by Semarang government, University authority, and trans Semarang operators so the built environments shall be integrated into urban streetscape fabric with high accessibility issues (Harsritanto B. I., 2018)

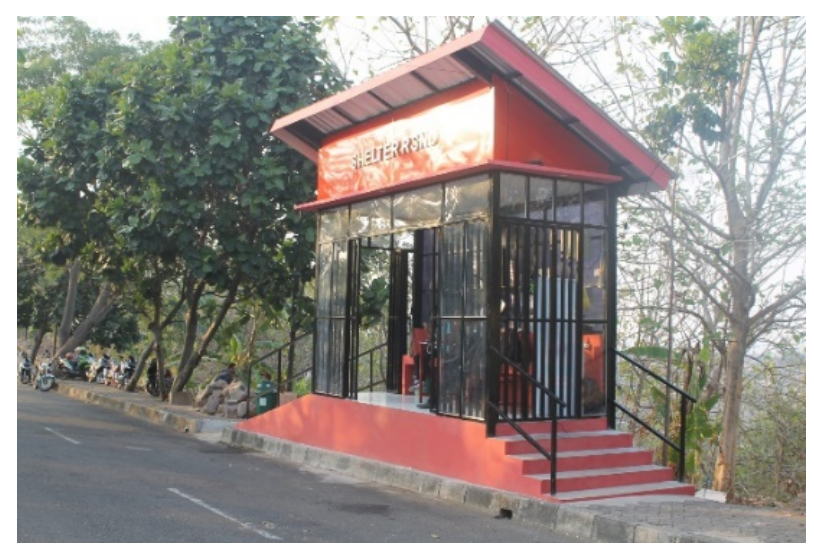

Figure 1. The common shelter condition in Undip 


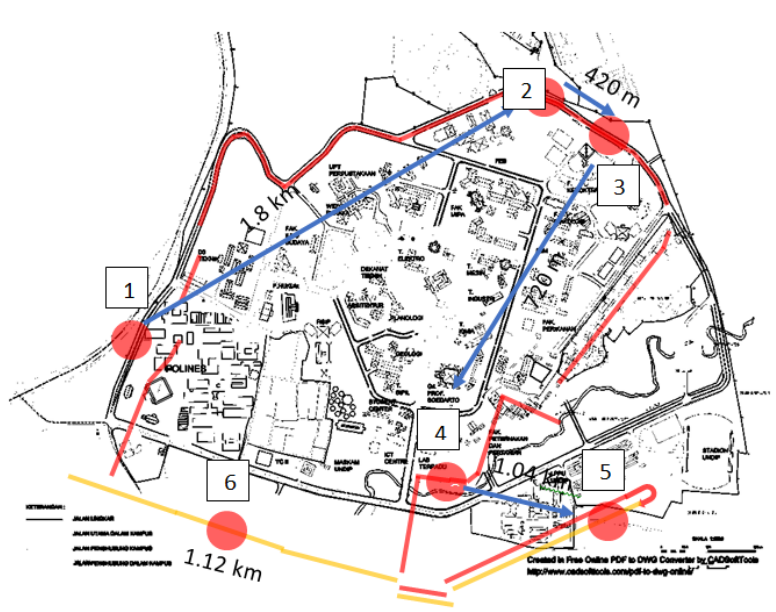

Figure 2. The shelter points and distances

\section{Distance Evaluation}

Many countries were failed to pursue their initial development strategy targets and later afterwards applied a more specific and essential strategy in which it introduced three innovative growth constructions: smart growth, sustainable growth, and inclusive growth. They claimed with confidence that urban development was positively able to improve quality of life (QoL) if the concept of growth replaces the idea of development. Following various innovative growth constructions or management principles, contemporary urban stuff include practical planners or official decision units, thus could pursue sustainable urban development and QoL simultaneously (Wey, Constructing urban dynamic transportation planning strategies for improving quality of life and urban sustainability under emerging growth management principles, 2019). Regarding the quality of life, shelter distances were regulated by the Indonesia governments. The principles of mixed zoning and land use are much seen as the basic in elaborating this regulation of land transport directorate-general in Indonesia.

The University of Diponegoro in Tembalang, Semarang can be pointed as mix high-density land use at zone 4 in periphery area neither the urban district. The location on the previously rural side of Semarang made this consideration, and the concentration of development is in the university area only. The consequences of these conditions shall be followed by the design of shelters located at every $300 \sim 500 \mathrm{~m}$ (see table 1). The land transportation directorate general mandated the local government to keep the distance of shelter to attract more citizens to use public transportation like Transemarang rather than to ride their private vehicle on daily city roaming activities (Purnomo \& Setiawan, 2018). The pinpoint of shelters in Diponegoro University might be scarce and not well located if we calculate the regulation on the shelter buildings (see figure 3 ). The various distance between the shelters was noticed in figure 2 to emphasized arguments of scarcer and unprepared design located on the university area.

Table 1. Shelter distance evaluation (Land transportation Directorate General, 1996)

\begin{tabular}{cccc}
\hline Zone & Landuse & Location & $\begin{array}{c}\text { Stop } \\
\text { distances (m) }\end{array}$ \\
\hline 1 & $\begin{array}{c}\text { High density office, } \\
\text { market, commerial } \\
\text { Office, school, } \\
\text { commercial }\end{array}$ & $\begin{array}{c}\text { CBD, } \\
\text { Urban }\end{array}$ & $\left.200-300^{*}\right)$ \\
2 & Urban & $300-400$ \\
3 & Housing & Urban & $300-400$ \\
4 & $\begin{array}{c}\text { Mix high density: housing, } \\
\text { school, commercial } \\
5\end{array}$ & Rural & $300-500$ \\
& farm low density: housing, & Rural & $500-1000$ \\
\hline
\end{tabular}

From figure 2, the red dots of shelter location were connected by the curve line to measure the distance between the shelters. The red lines are representing the campus route while the yellow is outside of the campus route. There were 2 outer ring road routes from point 1 to 2 and point 5 to 6 . This situation showed the connection between the shelters and demands to use the Tran Semarang on campus were not increased (Putra \& Kurnia, 2014) or there was no effort of a local provider (Diponegoro University or Semarang city governments) to check the passengers' data to update the locations (GelJahn, 1987) (Mehta, 2006).

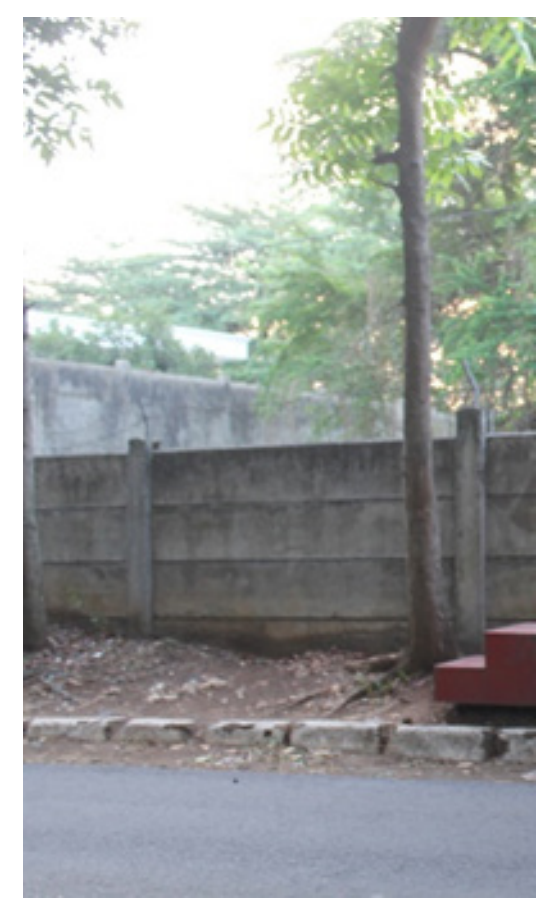

Figure 3. Condition of no leading pavement 
Table 2. Distance between the shelters

\begin{tabular}{ccccc}
\hline & Location & Distance & Road type & \multicolumn{2}{c}{ Evaluation } \\
\cline { 4 - 5 } Point connector & & & 300-500m & $>\mathbf{5 0 0 m}$ \\
\hline Point 1 - Point 2 & Vocational school - Hospital & $1,890 \mathrm{~m}$ & Outer ring road & $\mathrm{v}$ \\
Point 2 - Point 3 & Hospital - nutrition & $420 \mathrm{~m}$ & Inner ring road & $\mathrm{v}$ \\
Point 3 - Point 4 & Nutrition-agriculture & $782 \mathrm{~m}$ & Inner ring road & $\mathrm{v}$ \\
Point 4 - Point 5 & Agriculture - dormitory & $1,040 \mathrm{~m}$ & Inner ring road & $\mathrm{v}$ \\
Point 5 - Point 6 & Dormitory- Polines & $1,120 \mathrm{~m}$ & outer ring road & $\mathrm{v}$ \\
\hline
\end{tabular}

Table 2 showed that performed evaluation of distance between the shelters is easily predicted. From the five-line route between the shelters, five from six cases were out of standards. Assessment of the system using bus line of Transemarang under various customer demands: in low-demand situations, the total distance trip by the collaborative system profound to be smaller than using a direct delivery approach; however, as demand increases, the collaborative system significantly makes longer distances trip than a direct delivery system. The key is the size of the bus, as the Transemarang has low capacity and thus must establish many trips to satisfy demand. Nonetheless, these vehicles could be cleaner and less noisy than in the direct delivery scenario (Cleophas, Cottrill, Ehmke, \& Tierney, 2019). The distance of points 1 to 2, is the farthest of all and connected the Diponegoro University gate area from outside. Detecting this critical node of a Transemarang transportation network over time has two aspects: 1 . knowledge about the occupation index of nodes which likely helps develop strategies for support network resilience may vary over a day and between weekdays and weekends/ holidays, 2 . information about node criticality facilitates the management of public resources and the prioritization of funding demands. In this way, transportation planning becomes a proactive approach that balances the varying travel demands of citizens with the sustainable management of the transportation system (Psaltoglou \& Calle, 2018). The five only connections between point 2 to point 1 suited the standard of below $300 \sim 500 \mathrm{~m}$ distances. This ideal situation shall be followed by the next instalment of shelters to improve the service of Transemarang on the University of Diponegoro Tembalang campus if the bus size would not be resized or enlarge to meet the theories and demands. The installment of one more shelter on each line is a must strategy in this area. Otherwise, the coverage of passengers would not be increased and fail to compete with the increasing number of private vehicles (Firmanda, 2013). The tracking evaluation also showed that long-distance of each shelter was having potential threat for decreasing the Transemarang quality and lowers the passenger satisfaction for next phase of urban transportation system performed by local government (Irfana, Nugraha, \& Awaluddin, 2019).

\section{Shelter Design Evaluation}

The seven indicators were resumed into evaluation criteria on shelter design, such as leading pavement (pedestrian way connectors), guiding line (for blinds), door existence (for security and safety), ramps (for accessibility), stairs (for accessibility) furniture (for waiting for support amenities) and signage (for orientation). The seven indicators are the key design for applying the universal design principles (Minister of Public Works, 2006) (Minister of Public Works and People Settlements, 2017).

Six shelters on Diponegoro University showed many undesigned facilities for the passengers' comfort and access. The maximum number of not provided facilities (7) were scored in three shelters, (6) scored on none existence showed on shelter 4, and the (5) scored on two shelters of number 3 and 2. These conditions emphasized the condition of urban design at Diponegoro University, which was not planned properly. The urban design shall meet the buildings to increase the quality of life in certain environments, especially the transportation building and public service utilities (Watson, Plattus, \& SHibley, 2003) (Wey \& Huang, Urban sustainable transportation planning strategies for livable City's, 2018).

The situation of the inexistence of leading pavement on shelter 1, 2, 4, 5, 6 was observed in figure 2, for example. No leading pavement brought difficulties for the passengers to access the shelters. Despite the pavement, the bare soils were undeveloped to support these Transemarang facilities. The natural response of passengers usually uses the asphalt body of the road to access this shelter and may approach the danger of traffic accidents. 
Table 3. Shelter conditions

\begin{tabular}{|c|c|c|c|c|c|c|c|c|c|c|c|c|c|}
\hline & \multirow{2}{*}{ Indicators } & \multicolumn{2}{|c|}{ shelter 1} & \multicolumn{2}{|c|}{ Shelter 2} & \multicolumn{2}{|c|}{ Shelter 3} & \multicolumn{2}{|c|}{ Shelter 4} & \multicolumn{2}{|c|}{ Shelter 5} & \multicolumn{2}{|c|}{ Shelter 6} \\
\hline & & exist & none & exist & none & exist & none & exist & none & exist & none & exist & none \\
\hline 1 & Leading pavement & & $\mathrm{v}$ & & $\mathrm{v}$ & $\mathrm{v}$ & & & $\mathrm{v}$ & & $\mathrm{v}$ & & $\mathrm{v}$ \\
\hline 2 & Guiding line & & $\mathrm{v}$ & $\mathrm{v}$ & & $\mathrm{v}$ & & $\mathrm{v}$ & & & $\mathrm{v}$ & & $\mathrm{v}$ \\
\hline 3 & Door & & $\mathrm{v}$ & & $\mathrm{v}$ & & $\mathrm{v}$ & & $\mathrm{v}$ & & $\mathrm{v}$ & & $\mathrm{v}$ \\
\hline 4 & Ramp & & $\mathrm{v}$ & $\mathrm{v}$ & & & $\mathrm{v}$ & & $\mathrm{v}$ & & $\mathrm{v}$ & & $\mathrm{v}$ \\
\hline 5 & Stairs & & $\mathrm{v}$ & & $\mathrm{v}$ & & $\mathrm{v}$ & & $\mathrm{v}$ & & $\mathrm{v}$ & & $\mathrm{v}$ \\
\hline 6 & Furnitures & & $\mathrm{v}$ & & $\mathrm{v}$ & & $\mathrm{v}$ & & $\mathrm{v}$ & & $\mathrm{v}$ & & $\mathrm{v}$ \\
\hline \multirow[t]{2}{*}{7} & Signage & & $\mathrm{v}$ & & $\mathrm{v}$ & & $\mathrm{v}$ & & $\mathrm{v}$ & & $\mathrm{v}$ & & $\mathrm{v}$ \\
\hline & results & - & 7 & 2 & 5 & 2 & 5 & 1 & 6 & - & 7 & - & 7 \\
\hline
\end{tabular}

The ramp is also numerously unavailable on Diponegoro University bus shelter to support wheelchair users and traveller luggage. The ramp function supports the stairs inaccessibility for more various abilities of human (Harsritanto B. I., 2018). The stairs and ramps are complementary and substitution, as shown in figure 4 . Transportation for students means facilities that prove the activities and demands of students. Mainly the dormitory shelter shall be provided with the ramp since students usually move out from dorm with luggage for homecoming seasons (Miro, 2009). This certain opportunity has usually been caught by online ojek (taxis) to deliver the passengers to their destination on airports or stations with relatively cheap and comfort facilities (Silalahi, Handayani, \& Munajat, 2017). Furniture like bench and railing attached with no proper dimension didn't make these facilities meet the requirements. To fulfil the furniture/seat requirement, the Transemarang crews bring their chair and desk to the shelters as can be seen in figure 3 left side.
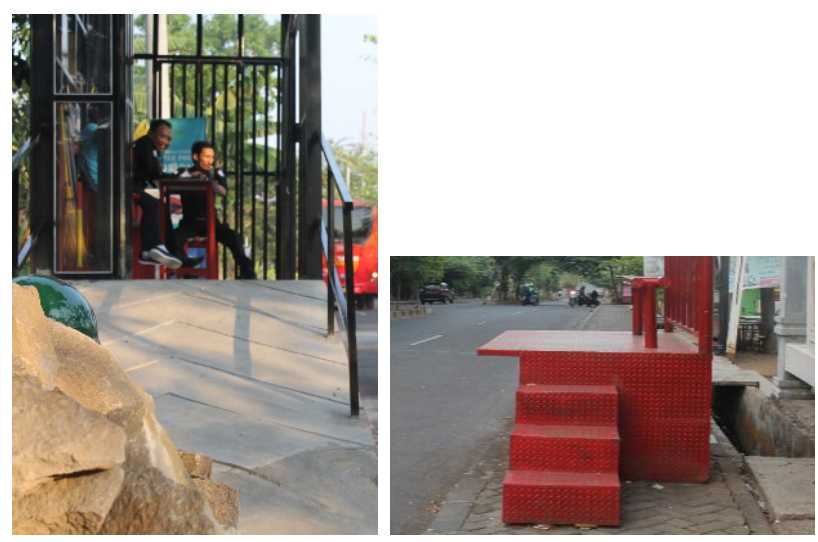

Figure 4. Condition of ramp, stairs, and furniture

\section{Customer Perception}

Conducting the questionnaire's responses, the majority of passengers use the Transemarang because it's cheap, take the ride on agriculture faculty (shelter 4 ) with $5 \sim 10$ minutes waiting time, and notice that the shelter is not comfortable because it's hot (see table 4). Scored perception can be studied to improve the Transemarang and Diponegoro University facilities as well as collaborations. The satisfaction of customers may increase loyalty, reduce the risk of customer turning cycles, lower the customer sensitivity toward ticket fares, decrease marketing cost, and step down the operation cost on customer situations (Aminah \& Zaenuri, 2019). Furthermore, (Azhari, 2011) the relation between service quality, ticket fare, and built facilities was a bond of the successful transportation system.

Table 4. Customer perception toward BRT Transemarang

\begin{tabular}{|c|c|c|c|}
\hline No. & Question & $\begin{array}{c}\text { Number of } \\
\text { response } \\
\text { (major) }\end{array}$ & Answer \\
\hline & BRT Transemarang ride & 29 & experienced \\
\hline & Reasons to ride BRT & 20 & cheap \\
\hline & Favorite waiting shelter & 28 & $\begin{array}{l}\text { Agriculture } \\
\text { Faculty }\end{array}$ \\
\hline & Fastest waiting time & 28 & 5 minutes \\
\hline & Longest waiting time & 28 & 10 minutes \\
\hline & Shelter location distant & 32 & short \\
\hline & Shelter condition & 32 & Not good \\
\hline & Comfortness in waiting & 29 & Not comfort \\
\hline & Reason of comfortness & 22 & Hot \\
\hline
\end{tabular}

The cheap fare of 3500 IDR showed a significant influence on customer shifting habit from private vehicles into public transportation. Recently, the Fintech industries also support the cheaper Transemarang ticket. The hope of reducing the usage of individual car/motor is still accessible if we see these conditions.

For further development, the agriculture faculty shelter shall be improved. More passengers may visit this favourite shelter in the future. The facilities such as a ramp, lower inclined stairs, better pavements, instalment of doors, and proper bench shall be installed in next events to 
increase the comfort of passenger waiting situations. Furthermore, the more enclosure and suitable roof must be built, since the passengers feel that the highest factor of comfortability is a hot condition while waiting for the bus.

In the waiting time of 5 10minutes, it is still reasonable for the passengers (Cleophas, Cottrill, Ehmke, \& Tierney, 2019) (Kumbhar, Survase, Mastud, \& Salunke, 2016). The clear real-time waiting time information can be provided by the Transemarang operators who have already been developed by the application of Transemarang. The app for smartphones based on Google maps and bus GPS devices and websites of Transemarang showed that the operators are giving their effort to satisfy their customers.

\section{Conclusions}

The conditions of Transemarang bus shelters on the Diponegoro University campus area are below the government standards. The distance between the shelters must be lowered, and the facilities on the shelter must be improved to meet the customer's demands. The progressive efforts to improve the bus rapid transportation quality by operators of Transemarang, Semarang government, and Diponegoro University have been made. However, the efforts need to be more intended and focus on bringing a better quality of service.

\section{Acknowledgements}

This research was financially supported by The Faculty of Engineering, Diponegoro University, Indonesia through Strategic Research Grant 2019. It was an advanced version of research design architecture subject of bachelor degree in architecture collaboration of student Agasthia Villianggie, supervisor Bangun IR Harsritanto, coordinator Hermin Wrediningsih and external collaborator of Rona Fika Jamila.

\section{REFERENCES}

[1] Aminah, S., \& Zaenuri, A. (2019). studi tentang kepuasan pengguna "brt trans". Serat Acitya - Jurnal Ilmiah UNTAG Semarang, 62-72.

[2] Azhari. (2011). Pengaruh Kualitas Pelayanan,Tarif dan Fasilitas Terhadap Kepuasan Penumpang Bus BRT Trans Semarang. Semarang: Universitas Diponegoro.

[3] Cleophas, C., Cottrill, C., Ehmke, J. F., \& Tierney, K. (2019). Collaborative urban transportation: Recent advances in theory and practice. European Journal of Operational Research 273, 801-816.

[4] Firmanda. (2013). Sistem Informasi Geografi untuk Evalusai Lokasi Shelter Bus Trans Semarang. Yogyakarta: Universitas Gadjah Mada.
[5] Gel, J. (1987). Life Between Building. New York: Von Nostrand Reinold.

[6] Harsritanto, B. I. (2018). Sustainable Streetscape Design Guideline based on Universal Design Principles. MATEC Web of Conferences 159

[7] Harsritanto, B. I. (2018). Urban Environment Development based on Universal Design. ICENIS 2017. Semarang: E3S Web of Conferences 31, 09010 (2018).

[8] Irawan. (2004). Kepuasan Pelayanan Jasa. Jakarta: Erlangga.

[9] Irfana, W. R., Nugraha, A. L., \& Awaluddin, M. (2019). pembuatan aplikasi peta rute bus rapid transit (brt) kota semarang berbasis mobile gis menggunakan smartphone android. Jurnal Geodesi Undip, 228-237.

[10] Kumbhar, M., Survase, M., Mastud, P., \& Salunke, A. (2016). Real Time Web Based Bus Tracking System. International Research Journal of Engineering and Technology. Vol. 3(2), 632-635.

[11] Land transportation Directorate General,. (1996). Keputusan DIRJEN Perhubungan Darat nomor:271/HK/.105/DRJD/96. Jakarta: Land transportation Directorate General.

[12] Mehta, V. (2006). Lively Streets: Exploring The Relationship Between Built Environment And Social Behaviour. Maryland: University of Maryland, College Pakr.

[13] Minister of Public Works and People Settlements,. (2017). Permen PUPR no.14 tentang Kemudahan Aksesibilitas Bangunan Gedung. Jakarta: MInistry of Public Works and People Settlements.

[14] Minister of Public Works, . (2006). Keputusan Menteri Pekerjaan Umum no 30 tahun 2006 tentang Pedoman Teknis Fasilitas dan Aksesibilitas pada Bangunan Gedung dan Lingkungan". Jakarta: Republic Indonesia, Ministry of Public Works.

[15] Minister of Transportation, . (1993). Keputusan Menteri Perhubungan No 65 Tahun 1993 Tentang Fasilitas Pendukung Kegiatan Lalu Lintas dan Angkutan Jalan. Jakarta: Ministry of Transportation.

[16] Miro, F. (2009). Perencanaan Transportasi bagi mahasiswa, Perencana dan Praktisi. Jakarta: Erlangga.

[17] Psaltoglou, A., \& Calle, E. (2018). Enhanced connectivity index -A new measure for identifying critical points in urban public transportation networks. international journal of critical infrastructure protection 21, 22-32.

[18] Purnomo, A., \& Setiawan, M. F. (2018). The Feasibility of BRT Corridor VI Shelters in Semarang City. AIP Conference Proceedings 1941, 0200251-02002511.

[19] Putra, T. A., \& Kurnia, A. S. (2014). Analisis Preferensi Masyarakat Terhadap Bus Rapid Transit (BRT) Trans Semarang. Diponegoro Journal of Economics III (1), 1-14.

[20] Putri, T. A. (2014). Analisis Cakupan Pelayanan Shelter Bus Trans Semarang Terhadap Kawasan CBD. Jurnal Geodesi Undip, 300-314.

[21] Silalahi, S. L., Handayani, P. W., \& Munajat, Q. (2017). Service Quality Analysis for Online Transportation Services: Case Study of GO-JEK. Procedia Computer Science 124, 
487-495.

[22] Watson, D., Plattus, A. J., \& SHibley, R. G. (2003). Watson, Donald. Dkk 2003. Time saver for standart for urban design. Mc-Graw-Hill Profesional. USA. New York: Mc Graw Hill Profesional.

[23] Wey, W.-M. (2019). Constructing urban dynamic transportation planning strategies for improving quality of life and urban sustainability under emerging growth management principles. Sustainable Cities and Society 44, 275-290.

[24] Wey, W.-M., \& Huang, J.-Y. (2018). Urban sustainable transportation planning strategies for livable City's. Habitat International 82, 9-27. 